\title{
Listening Skills: Accountancy Educators in Retreat?
}

\author{
Alan Reddrop ${ }^{1}$ and Gido Mapunda ${ }^{2}$
}

\begin{abstract}
Purpose: to gain insight into the training received by accountancy graduates in soft skills with a major focus on listening skills; and, both, in light of findings, and impelled by the pleas of accountants' clients, to urge educators to introduce them in curricula.

Approach: content analysis of Australian accountancy schools' courses placed on the web followed by direct contact with schools whose Web descriptions might plausibly have indicated listening skills' inclusion;

Findings: while the Institute of Chartered Accountants in Australia and CPA Australia required in their Professional Accounting Guidelines, 2009' that as a condition of their accreditation higher education programs address 'generic skills' including the interpersonal, 'particularly the ability to listen effectively', this was scarcely complied with by accredited schools . Subsequent to the 2009 ICAA/CPA directive successive pronouncements of the Institutions reduced or effectively eliminated the requirement to teach listening skills.

Practical implications: accountancy graduates will enter the profession without groundwork in a skill which successful exponents will increasingly be required to exercise. This will need to be remedied.

Originality value: empathetic listening skills are seen to be indispensable by reference to the demands of a party not considered in previous studies, namely practising accountants' clients. Nor have previous studies adequately recognised the critical importance of these skills as artificial intelligence (AI) erodes accountants' standing as dispensers of technical knowledge.
\end{abstract}

\section{Keywords}

listening skills, accountants’ clients’ needs, accountancy educators, artificial intelligence.

JEL classification: M41, I23.

\footnotetext{
${ }^{1}$ University of South Australia.

${ }^{2}$ University of South Australia.
} 


\section{INTRODUCTION}

This article discusses the status of listening skills, within broader empathetic soft skills, as part of accountants' successful practice. . It does not examine broader 'communication' skills. These have been well covered in the literature, coverage well summarised, for example, by Evans et al. (2012), while Parks (2015, p.2) observes that 'listening is often overshadowed by speaking in communications research'. 'Outward' communication is studied at length, moreover, in O'Connell et al. (2015) to which we refer below. Our focus on listening skills reflects a concern expressed by practising accountants' clients who, as we document, plead to be listened to more; instructed less.

We examine the extent to which teaching of listening skills is required of accountancy schools as a condition of accreditation by the Institutions in Australia; whether and how they are inculcated; and how Institutions 'requirements have evolved in the last decade.

A content analysis was conducted of accountancy schools' courses as they are summarised and described on university websites. Further information was sought from the four schools whose course descriptions implied concern with listening skills while not explicitly referring to them.

This article has significance, first, because it introduces a viewpoint about accountants' listening skills that previous literature largely ignores, namely that of their clients; secondly because it foresees a time when the possession of listening skills and the empathy that lies behind them will remain in demand when many technical skills have been supplanted by automation, this process being foreseen comprehensively by Susskind \& Susskind (2017) to which we refer later.

\section{PREVIOUS LITERATURE}

Bodie (2011), a communications scholar writing for fellow scholars, declares that 'listening is not "mainstream" interpersonal communications research' and concludes that listening should receive more serious attention in communication scholarship. Neglect may arise from its 'often acting as a hidden process that is difficult to observe and measure' (Parks 2015, p.14). Parks notes that while it is emerging in studies of healthcare it is neglected in business studies. Where it is recognised, 'it is often overshadowed by speaking in communications research' (p.2).

Stone and Lightbody (2012) identify a like deficiency in the operational field of accounting. One source they cite, Gouws and Terblanche (1998), estimate that listening and talking comprise two-thirds of accountants' communication with colleagues and clients, but that listening skills are not nurtured in proportion to the importance of these skills in professional practice. The same authors cite multiple sources indicating that 'accounting practitioners and the employers of accounting graduates consider listening to be the most important or amongst the most important oral communication skills' (p.64) required of graduates. The need for such skills was also identified among accountancy school alumni surveyed by Carr et al (2006). They found 'Communication (oral, written and listening)' was one of the two competencies that almost all of their 233 respondents expected accounting graduates to have. These findings are reinforced by Siriwardane et al. (2015) interrogating accountants in Singapore. The studies provide evidence of the need for educators to address listening skills in accounting curricula 'more explicitly'. These were perceived by employers 
as being most important and should be grounded in oral communication modules. In contrast, educators were inclined to include individual oral presentations in their curricula, but such were found not to be highly prized in new graduates by accounting employers (Gray \& Murray 2011, p.238). The essence of this finding was provided by the interviewee who maintained:

listening to another person as being a more important skill than that of articulating one's own thoughts...Sometimes speaking less is better than speaking more.

This permitted 'reflective adjustment to an audience's preferred register'.

Twomey (2004) goes further in maintaining that by 'empathetic listening' accountants' very status as suppliers of financial and related information is 'protected and enhanced [in] being able to put themselves in the position of users of that information'.

Jones and Abraham (2009, pp.49-50) maintain that 'Interpersonal attributes, including demonstrating empathy', are 'highly desired' and need to be 'reinforced and developed during accounting education'. The need is the more necessary in that accountancy students are shown to have lower emotional intelligence skills than students in, say, liberal arts programs, see Jones \& Abraham (2009) and Cook et al (2011). Furthermore, accountancy students are more 'apprehensive' than others in engaging in oral communication (Daff 2013). Interestingly, a recent study found that graduating accountancy students regarded listening [and reading] skills the least important communication skills related to employability ('negating the views of employers who perceive them to be highly essential for new accountants' (Pia Patricia 2017)). Stone and Lightbody (2012) conducted interviews with practising accountants whose clients included small business operators and managers. The views expressed to them strongly validated previous findings regarding the significance of listening skills. To similar effect, Tempone et al. (2012) asked employers to rate listening skills. Those considered most important were 'listening attentiveness and listening responsiveness'. A cognate emotional intelligence is seen as essential by (Low et al 2013) and by Nugent (2016), while Parks (2015, p.11) maintains ‘empathy and relational listening are inherently tied together’.

Stone and Lightbody (2012) propose many ways integral to the teaching curriculum in which accountancy educators could foster development of listening skills among their students (p. 378). These included the appointment of a 'primary listener' during presentations by their peers who is subsequently assessed for their listening performance; the delivery to students of incomplete handouts that required to be completed during a lecture; the setting of group tasks in which members were encouraged to 'exercise attentive and responsive listening' (p.378). The authors urge educators to address listening skills in accounting curricula more explicitly. They call for further scholarly enquiry into the possibilities of introducing listening development in the accountancy curriculum.

This appears not yet to have happened on an appreciable scale.

Daff (2013) describes how a program to develop accountancy students' interpersonal skills was implemented. It took advantage of material on interpersonal skills in a leadership program devised by Caleb Leadership Ministries in which she participated; also from the author's study of methods developed over many years for medical students. It entailed requiring students to engage in conversations with fellow students on inter alia listening skills. Students' experiences were recorded in 'learning journals' which subsequently formed the material on which students' learning was assessed. 
Similarly, Butler (2016) describes a‘ Probability Evaluation Game’ (PEG), an innovative teaching instrument which she introduced to emphasises the sophistication of listening and highlight listening as a key skill for accounting practitioners.

The voices of Daff (2013) and of Butler (2016) appear to echo in an international void. Other than these, Apostolou et al (2013; 2015, 2016, 2017, 2018) record no treatment of listening skills in their content analysis of six leading accountancy education journals in recent years.

True, somewhat tangentially, the Report of the American Accountancy Pathways Commission (2012) established to advise on the future structure of higher education for the American accountancy profession, ordains that students should be required to 'Question [their] understanding of others' communication and remain sensitive to cultural and language differences' (p.17). But no reports of its implementation have been located.

There may have been a greater impetus to introduce listening into the accountancy curriculum if the voice of a most significant party had been heeded and recorded, namely, that of practising accountants' clients, the purchasers of their services. This appears not to have happened No record of it has been located - other than in the obscurity of the present first author's doctoral thesis (hereinafter, Reddrop (2012)..

Clients' views are critical for the survival and prospering of accounting firms, and thus their opinions are recorded in detail here. Participants in Reddrop (2015) were the CEOs and senior managers of family businesses, the most prolific type of business in Australia, New Zealand and other parts of the world (Cappuyns et al. 2003). The study illuminated family business's propensity to seek the services of advisers, mainly accountants, and their satisfaction with the experience delivered. As part of this study an internet survey of 140 CEOs was supplemented and enhanced by 51 in-depth, semi-structured interviews, 28 with CEOs and some of their senior colleagues and, to provide corroboration (or not), with 19 advisers of whom ten were accountants.

A client who spoke for many said,

To me, the first role of an adviser is to sit and listen and gather information, The current advisers just don't do that. They tend to walk straight in and tell you what's wrong and how to run your business CEO (C1) interviewed in research for Reddrop (2012, p. 112 ).

CEOs spontaneously used the term 'empathy' time and again in describing advisers' desirable attributes. Terminology such as 'warmth', 'consideration', were used often and even 'kindness'. These highly regarded skills are enabled by the active listening valued by clients. The expressions were notable for their frequency and intensity, evident not only in the words used but the force with which they were delivered, sometimes giving the impression they were 'pent up', awaiting an opportunity for their articulation. Thus, a client recalling an initial conversation with a would-be adviser said:

I'm trying to work out whether what I think is going to work and straight away they're gonna tell me what they think is going to work...but I need to get that empathy about where I'm coming from and what it is I'm looking for (C20).

On where they found it lacking they expressed views similar to that which prefaces this section. 
Such sentiments were expressed unprompted by CEOs in numerous interviews. By contrast, a good adviser was identified because, 'you felt you were being heard: he was a good listener' (C14).

Experienced advisers concurred, for example:

You've got to talk about things that are relevant to [the client], and $80 \%$ of that comes down to using the right proportion, the ears versus the mouth (A35).

They [some other advisers] often give advice: it's premature, it's off-target, it sounds plausible, it doesn't work, it can't be implemented; simply because they haven't taken the time to come to grips with the real issue, or understand the person (A52).

Possession of such an outlook was characteristic of those accountants who in their clients' opinions were superlative practitioners, and, in the view of the interviewer, represented 'those at the pinnacle of the advisory profession'. They had attained this through maturity and sometimes through experiencing earlier in their careers a program of mentoring by or 'shadowing' of senior, seasoned colleagues. None professed to have gained it during tertiary education (Reddrop 2012, p.112).

Listening has been recognised as the progenitor of trust:

Listening...is the stage in the process where the client comes to believe that the advisor understands him and her. The purpose of listening in building trust is to earn the right to engage in a mutual exploration of ideas. (Maister et al. 2000, pp.86-87).

Several disciplines, among others medicine, management and marketing report on the importance of creating trust and rapport to establish professional working relationships that result in collaboration (Kochan \& Trimble 2000), Butler (1991) in his seminal work on conditions of trust inventory (p. 643) identifies two trust-builders consistent with collaborative communication: being a good listener and openness (sharing one's thoughts and information).

\section{METHODOLOGY}

After undertaking the literature review which yielded the material in the last section we interrogated the Websites of Australian universities offering accountancy courses. The starting point was the Australian Education Network's 'Accounting Schools in Australia' (2017) . This purported to lead directly to the universities' relevant Web pages. In the event it was necessary to go directly to the Web pages of 26 universities offering accountancy courses. A content analysis was conducted of descriptions of accountancy courses and of business courses offering accountancy modules. Words or phrases searched for were listening (one occurrence), communication and interpersonal and oral skills. Note was made of opportunities for internships and industry placements which were thought to offer the prospect of relevant tacit instruction. Further inquiries were made in person or by email when universities' material appeared most relevant for our purposes. Results are related in the section next but one. 


\section{ACCREDITATION GUIDELINES OF 2009}

The Institute of Chartered Accountants in Australia and CPA Australia issued Professional Accounting Guidelines. They required, inter alia, that as a condition of their accreditation higher education programs address 'generic skills' including the interpersonal, 'particularly the ability to listen effectively (ICAA and CPA (2009, p.12). They require that the teaching of generics skills be incorporated in the 'core curriculum'.

\section{ACCOUNTANCY SCHOOLS’ RESPONSES}

To assess compliance with the above requirement a content analysis was conducted of the curricula of 24 Australian accountancy (or commerce including accountancy) schools as described on their Web pages. It seemed a reasonable supposition that 'core' aspects of the curriculum would be included therein. Since all have ICAA and CPA accreditation they might be expected to echo or paraphrase the Institutions' requirements. No such references were found. Attempts to identify statements that reflected the spirit of the above delivered very few positive results.

Southern Cross University's Bachelor of Accounting course (2019) includes a component, 'Communication in organisations'. That, in turn, includes a module, 'Essentials of interpersonal communication', consisting of 'communication theory and practice, non-verbal communication and personality, listening and feedback'. Among all the curricula this was the sole instance of the word 'listening' occurring.

'Communication' occurred frequently in the assessed web-pages and course outlines, but mostly denoting written or oral expression of concepts. Thus, upon successful completion of Charles Sturt University's Bachelor of Accounting (Professional Practice in Accounting) course (2019) 'students should be able to communicate effectively in the workplace'. Deakin University's Master of Professional Accounting (2019) will 'enhance understanding of professional practice, reporting, communication...'. Macquarie's Accounting in Society course (2019). aims to 'develop graduate capabilities centred on discipline specific knowledge and their application to problem solving, with one particular outcome being the demonstration of communication skills'. Its Master of Accounting with a specialisation in Professional Practice has 'a strong focus on communicative competence as well as technical skills'. Victoria University's Graduate Diploma in Business (Accounting) course (2019a) teaches how to 'effectively communicate complex knowledge and ideas to a variety of audiences'. While by its Master of Business (Accounting) course (2019b) graduates will be able to 'communicate effectively to specialist and non-specialist audiences including multidisciplinary teams, diverse cultural communities and business and other professional organisations. Sydney University's Master of Professional Accounting program (2019) 'reinforces technical excellence in [specified] fields within a framework that emphasises core professional competencies in, [inter alia], professional communication and persuasion'. Western Sydney University's Master of Professional Accounting (Advanced) course (2019) offers 'the opportunity for students to improve research skills, and to develop logical arguments and analytical skills in a business context along with enhanced communication skills'.

In some of the investigated universities, students can be provided with internships or with opportunities to network with professionals. These are not explicitly aimed to develop soft (including listening) skills but they might be an implicit attempt to develop them through their observation of the exercise of well-developed inter-personal and professional skills. For 
example, Murdoch University provides an opportunity for Master of Professional Accounting students (Murdoch University 2019) 'to get practical experience in professional placements through our Work Integrated Learning program’. Queensland University of Technology can offer accountancy students 'a work placement with selected industry employers' enabling them 'to apply theoretical knowledge, and develop skills and understanding in a real-world environment' (Accountancy in practive 2019)..

It was considered possible that the required skills might be addressed in discipline specific modules even though the terms might not appear in module titles. Accordingly, we approached heads of school or senior academics in four of the schools whose course descriptions might most plausibly cover the ground required by the Institutions. Three of the four admitted to no such coverage. The fourth, however, did include 'active listening [as] a key part of business communication'. Key elements were: paying attention, showing you were listening, providing feedback, responding appropriately, and withholding judgment. While the process and appearance of listening were covered the course did not touch on the empathetic or emotional. It might be unreasonable, however, to expect its inculcation remote from a real-world interlocutor's feelings.

Again, it is possible that listening and broader communication skills might be addressed in courses extraneous to the accounting syllabus. This was not investigated. The accreditation guidelines required generic skills to be part of the 'core (accounting) curriculum'. We note, too, the emphatic views of Jones (2010) that generic attributes must be understood as part of the professional and scholarly practice of accounting and so taught as integral to disciplinary practice.

\section{POST 2009 PRONOUNCEMENTS}

As noted above, listening skills feature prominently in the 2009 Guidelines.

In 2015, commissioned by CPA Australia, the heads or senior members of five Australian university accounting schools undertook a study, 'Shaping the future of accounting in business education in Australia' (O'Connell et al. 2015) which investigated the existing state of play in accounting business education and 'with a prospective focus' assessed key challenges and opportunities they faced in order to develop 'feasible, innovative and productive ways forward' (p.v).

To what extent do O'Connell et al. (2015) acknowledge the importance of the skills to which previous authors had given attention, including those quoted in previous paragraphs? Scarcely. In a work of some 54,000 words the words 'listen' or 'listening' appears four times: once in a section on definitions, once in a direct quotation, once within the main argumentation and once in an appendix. The word 'empathy' appears once only, in a quotation. 'Warmth' and, 'kindness' do not appear anywhere in the report.. None of these terms identified here featured explicitly in the recommendations section of the report. This lacuna can possibly be explained, in part, by omission of accountancy firms' clients among the parties from whom the study sought views. However, further investigation indicated that the authors were, indeed, acquainted with the research on listening skills. For example, one of the authors of O'Connell et al. (2015) was the head of school in which Stone et al. (2013) produced their high-impact article on 'The nature and significance of listening skills in accounting practice'; also, the earlier article, Stone and Lightbody (2012). These articles were not cited. 
O'Connell et al. (2015) devote considerable attention to 'Technology' and what changes it will portend for accounting. The relevance of this in relation to listening and empathetic skills is not considered. A discursive chapter treats of 'enabling' technologies. It foresees

Exciting challenges as curricula are transformed by key enabling technologies and the new realities of the profession in an increasingly globalised world (p.v)

They recognise

The future of work being heavily influenced by the adoption of key enabling technologies..., (p.53)

They note that 'accounting in the future will require different skills '(p.88). While their nature was not defined, they recommend employing

Instructional designers with experience in key enabling technologies to assist accounting academics with the deployment of relevant technology in their teaching. (p.94)

Technology, thus, is a necessary appurtenance to be recognised in the curriculum, not least so academics can keep abreast of their savvy students. It is seen as an enabler. In a work avowedly looking to the world of 2024 it is surprising that it is not seen also as a displacer. The growing roles of intelligent machines and their implications for the exercise of generic skills are unacknowledged - even though they are foreshadowed in previous studies. And even if O'Connell et al. (2015) were sceptical of such predictions it is surprising that they do not indicate awareness of them, if only to counter them.

Accounting Learning Standards (Hancock et al, undated, but circulated in 2016) is an authoritative work being prepared under the auspices of the Accounting and Finance Association of Australia and New Zealand (AFAANZ) and endorsed by the Australian Business Deans Council. It enunciates six 'learning standards' one of which concerns 'communication'. It requires masters' degree students to be able to

Justify and communicate accounting advice and ideas in complex contexts to influence specialists and non-specialists (p. 8)

(A similar but less rigorous standard is required of bachelors' degree students).

The requirement is expanded in a 'commentary':

In communicating ideas the Master graduate must have strong verbal and written skills that present information in a logical, understandable and compelling format when being shared with various stakeholders (p. 13).

The document bears evidence of a similar pedigree to O'Connell et al. (2015) having two authors in common. However the latter's vestigial references to listening and soft or generic skills have vanished. Moreover, its content differs from that of a cognate work, the Initial Professional Development - Professional Skills (Revised) of the International Education Standards Board (2014, p.46): its learning outcomes include a 'competency area', interpersonal and communication. This requires, inter alia, ability to 'apply active listening skills and effective interviewing techniques'. 
Simple oversight must be discounted in a document issued by AFAANZ, having been 'circulated to all accounting schools/departments and professional bodies' for comment and approval.

Clearly, this indicates a diminishing recognition of the importance of soft, including listening' skills in the schools and Institutions.

Accreditation Guidelines of 2018, in full, Professional Accreditation Guidelines Australia and New Zealand (2018): supersedes the 2009 (and a 2012) edition. The requirement of the first that higher education programs address interpersonal skills, 'particularly the ability to listen effectively' is absent. Instead, a section headed, 'Interpersonal and communication skills' lists expected abilities, the seventh and last of which is, 'listen and read effectively, including a sensitivity to cultural and language differences'. The fact that 'listen' is yoked with 'read' robs the former of interpersonal and empathetic weight: a significant change. This possibly reflects the standpoint of O'Connell et al. (2015).

In sum, we observe a diminishing recognition of the importance of listening skills in successive authoritative documents. We observe, too, scant compliance by the schools even when the skills were specified by the Institutions.

\section{THE ADVENT AND GROWTH OF ARTIFICIAL INTELLIGENCE (AI)}

Hazelton \& Marrone in their call for papers in Meditari Accountancy Research (2017) on new technologies observe that the changes they engender may not be 'benign'. They cite Susskind \& Susskind (2017). These authors maintain that 'increasingly capable machines will take on many of the tasks that have been the historic preserve of the professions' (including accountants); that more and more tasks that once required human beings were being performed 'more productively, cheaply, easily, quickly and to a higher standard by a range of systems' (p.159). Other authors are specific: 'Only one percent of "tax preparation work" is safe from computerization' (Frey \& Osborne 2013); and that artificial intelligence (AI) would be applied to much of the auditors' work (Liddy 2014). The impending growth in the role of AI has be acknowledged by a most authoritative source, viz, The International Association of Chartered Certified Accountants (ACCA 2016) and thus a corresponding need to foster residual human skills:

Professional accountants of the future will need to develop and demonstrate the ability to combine their technical knowledge, skills and abilities with softer skills concerned with interpersonal behaviours and qualities.( p.26)

Susskind \& Susskind (2017) envisage a day when machines could 'play a role' even in the deployment of empathetic skills, but this was not expected to take place 'for some years in the future '(p.265). Possession of soft, including listening, skills could therefore constitute a bridgehead enabling the accountancy profession to preserve its traditional métier for longer (if not indefinitely), that is, after more technical processes became mechanised. For this to happen, however, accountancy educators would need to admit generic skills into their curricula to a greater extent than at present. It might be noted, however, that Susskind \& Susskind (2017) are sceptical. They fear that:

elaborate and sophisticated methods and institutions for the development of professionals are configured today to bring through a new generation of twentiethcentury professionals (p.262). 
And that these obsolescent procedures were being propagated by 'an older generation... who are responsible for education policy'. While specifically in accounting education, an 'aging, change-resistant faculty limit the number of actors with both the power and the will to change the status quo' (de Villiers 2010, p.12, referencing Walker \& Black (2000)). This blindness by accounting educators to the demands of the professions conforms with a wider deficiency cogently identified by Bayerlein and Timpson (2017) such that graduates of accredited undergraduate accounting programmes in Australia are unlikely to meet the needs of contemporary accounting practice. Correspondingly, Guthrie \& Parker (2016) who detect 'a fashion for theoretical focus that risks being to the exclusion of other aspects such as methodology [and] actual findings' (p. 8).

\section{LIMITATIONS}

The study concentrates on the Australian scene. However, it may have relevance further afield. American universities are reported to have no curriculum available on client relationship skills which would embrace the soft skills discussed here (Grubman \& Jaffe 2010). In a worldwide perspective Kermis and Kermis (2010, p.5) maintain that 'faculty...have either actively or passively avoided addressing the evermore critical dimension of soft skills'.

Information on Australian accountancy schools' curricula was derived mainly from their descriptions on the Web. Only four schools' material was subject to more detailed examination. However, no relevant material was observed in three of these schools.

\section{CONCLUSION}

As recorded by Reddrop (2012), successful practising accountants and their clients recognise the importance of the soft skills, particularly empathetic listening, which engender trusting, collaborative and productive relationships. The Institutions, ICAA and CPA, also recognised this and reflected it in their Professional Accreditation Guidelines for Higher Education Programs of 2009. They required accredited schools to address in core curricula, inter alia, generic skills including the interpersonal, 'particularly the ability to listen effectively.' This condition was not widely complied with by accredited schools. In effect, skills which when acquired endure and are transferable appeared to be crowded out in accountancy courses by technical content which by its nature is transient.

Subsequent pronouncements by the Institutions eroded or removed the requirement. If followed, it means that accountancy graduates will be increasingly ill-prepared to pursue their calling in a setting in which the generic skills will become paramount as technical aspects of the function will be displaced by automatic intelligence.

This paper, noting in particular the emphatic views of accountants' clients, invites the Institutions and the schools whose curricula they guide to reinstate or adopt (as appropriate) the inclusion of listening skills within the broader generic skills in courses which will meet future graduates' needs. Students, practising accountants and, especially, the clients they serve would benefit. Furthermore, following Daff (2013) and Butler (2016) it recommends academic accountants to engage in and report on experiments to foster the inculcation of listening skills within accountancy courses. 


\section{REFERENCES}

AICPA, 2012, Report of the Pathways Commission: Charting a national strategy for the next generations of accountants. , AAA and AICPA, New York.

ACCA 2016, Drivers of change and future skills for professional accountants, Association of Chartered Certified Accountants, Glasgow, United Kingdom.

Apostolou, B, Dorminey, JW, Hassell, JM \& Watson, SF 2013, 'Accounting education literature review (2010-2012)', Journal of Accounting Education, vol. 31, no. 2, 2013/06/01/, pp. 107-61. https://doi.org/10.1016/j.jaccedu.2013.03.001

Apostolou, B, Dorminey, JW, Hassell, JM \& Rebele, JE 2015, 'Accounting education literature review (2013-2014)', Journal of Accounting Education, vol. 33, no. 2, 2015/06/01/, pp. 69-127. https://doi.org/10.1016/j.jaccedu.2015.04.001

Apostolou, B, Dorminey, JW, Hassell, JM \& Rebele, JE 2016, 'Accounting education literature review (2015)', Journal of Accounting Education, vol. 35, 2016/06/01/, pp. 20-55. https://doi.org/10.1016/j.jaccedu.2016.03.002

Apostolou, B, Dorminey, JW, Hassell, JM \& Rebele, JE 2017, 'Accounting education literature review (2016)', Journal of Accounting Education, vol. 39, 2017/06/01/, pp. 1-31. https://doi.org/10.1016/j.jaccedu.2017.03.001

Apostolou, B, Dorminey, JW, Hassell, JM \& Rebele, JE 2018, 'Accounting education literature review (2017)', Journal of Accounting Education, vol. 43, 2018/06/01/, pp. 1-23. https://doi.org/10.1016/j.jaccedu.2018.02.001

Australian Education Nework 2017, Accounting Schools Australia, viewed 3 March 2017, $<$ http://www.australianuniversities.com.au/schools/accounting/>.

Bayerlein, L \& Timpson, M 2017, 'Do accredited undergraduate accounting programmes in Australia meet the needs and expectations of the accounting profession?', Education + Training, vol. 59, no. 3, pp. 305-22. https://doi.org/10.1108/ET-04-2016-0074

Bodie, GD 2011, 'The Understudied Nature of Listening in Interpersonal Communication: Introduction to a Special Issue', International Journal of Listening, vol. 25, no. 1/2, pp. 1-9. https://doi.org/10.1080/10904018.2011.536462

Butler, C 2016, 'The probability evaluation game: an instrument to highlight the skill of reflexive listening', Accounting Education, vol. 25, no. 2, 2016/03/03, pp. 107-23. https://doi.org/10.1080/09639284.2015.1089178

Butler, J 1991, 'Toward Understanding and Measuring Conditions of Trust: Evolution of a Conditions of Trust Inventory', Journal of Management, vol. 17, no. 3, 1991/09/01, pp. 643-63. https://doi.org/10.1177/014920639101700307

Cappuyns, K, Astrachan, J \& Klein, S 2003, 'Family businesses dominate', viewed 4 September 2008, <http://www.iese.edu/en/files/6_10807.pdf.

$>$. 
Reddrop \& Mapunda | Listening Skills: Accountancy Educators in Retreat?

Charles Sturt University 2019, 'Bachelor of Accounting course', <http://www.csu.edu.au/handbook/handbook18/subjects/ACC275.html

Cook, GL, Bay, D, Visser, B, Myburgh, JE \& Njoroge, J 2011, 'Emotional Intelligence: The Role of Accounting Education and Work Experience', Issues in Accounting Education, vol. 26, no. 2, pp. 267-86. https://doi.org/10.2308/iace-10001

Daff, L 2013, 'Accounting students' ref;ections of a course to enhance their interpersonal skills', Accounting Education, vol. 22, no. 6, pp. 563-81.

https://doi.org/10.1080/09639284.2013.847322

de Villiers, R 2010, 'The incorporation of soft skills into accounting curricula: preparing accounting graduates for their unpredictable futures', Meditari Accountancy Research, vol. 18, no. 2, pp. 1-22. https://doi.org/10.1108/10222529201000007

Deakin University 2019, 'Mater of Professional Accounting course', <https://www.deakin.edu.au/__data/assets/pdf_file/0005/43556/2014-MPA-Jun18.pdf>.

Evans, C, Gbadamosi, G, Wells, J \& Scott, I 2012, 'Balancing the Yin and Yang: The Role of Universities in Developing Softer Skills in Accountancy', Industry and Higher Education, vol. 26, no. 1, pp. 63-70. https://doi.org/10.5367/ihe.2012.0081

Frey, C \& Osborne, M 2013, The future of employment: how susceptable are jobs to computerisation, viewed 18 April 2017, $<<$ http://www.oxfordmartin.ox.ac.uk/downloads/academic/The_Future-ofEmployment.pdf $>$ accessed 18 April 2017>.

Gouws, D \& Terblanche, A 1998, 'The accountant a facilitator of communication', Meditari Accountancy Research, vol. 6, pp. 91-119.

Gray, FE \& Murray, N 2011, "A distinguishing factor': Oral Communication Skills in New Accountancy Graduates', Accounting Education, vol. 20, no. 3, pp. 275-94. https://doi.org/10.1080/09639284.2011.560763

Grubman, J \& Jaffe, D 2010, 'Client Relationships and Family Dynamics: Competencies and Services Necessary for Truly Integrated Wealth Management', The Journal of Wealth Management, vol. 13, no. 1, pp. 16-31,6. https://doi.org/10.3905/JWM.2010.13.1.016

Guthrie, J \& Parker, LD 2016, 'Whither the accounting profession, accountants and accounting researchers? Commentary and projections', Accounting, Auditing \& Accountability Journal, vol. 29, no. 1, pp. 2-10. https://doi.org/10.1108/AAAJ-10-2015-2263

Hancock, P, Watty, K, Birt, J \& Tyler, J undated, Accounting learning standards, AFAANZ.

ICAA \& CPA 2009, Professional accreditation guidelines for higher education programs, ICAA and CPA.

ICAA \& CPA 2018, Professional accreditation guidlines Australia \& New Zealand. 
Jones, A 2010, 'Generic Attributes in Accounting: The Significance of the Disciplinary Context', Accounting Education, vol. 19, no. 1-2, 2010/04/01, pp. 5-21. https://doi.org/10.1080/09639280902875523

Jones, G \& Abraham, A 2009, 'The Value of Incorporating Emotional Intelligence Skills in the Education of Accounting Students', Australasian Accounting Business and Finance Journal, vol. 3, no. 2.

Kermis, G \& Kermis, M 2010, 'Professional presence and soft skills: a role for accounting education', Journal of Instructional Pedagogies, vol. 2, pp. 1-10.

Kochan, FK \& Trimble, SB 2000, 'From Mentoring to Co-Mentoring: Establishing Collaborative Relationships', Theory Into Practice, vol. 39, no. 1, 2000/02/01, pp. 20-28. https://doi.org/10.1207/s15430421tip3901_4

Liddy, J 2014, The future of Audit, <<http://www.forbes.com $>$ accessed 18 April 2017>.

Low, MS, G, Liu, C. 2013, 'Accounting Education and the Provision of Soft Skills: Implications of the recent NZICA CA Academic requirement changes"', Journal of Business Education \& Scholarship of Teaching, vol. 7, no. 1.

Macquarie University 2019, 'Accounting in Society course', < http://handbook.mq.edu.au/2019/Units/UGUnit/ACCG100>.

Maister, D, Green, C \& Galford, R 2000, The trusted advisor, The Free Press, New york.

Murdoch University 2019, 'Professional Accounting course', $<$ https://www.murdoch.edu.au/study/courses/course-details/master-of-professionalaccounting-(mpa)\#course-description-and-structure $>$.

Nugent, B 2016, 'Why emotional intelligence matters', Accountancy Ireland, vol. 48, no. 6, pp. 88-89.

O'Connell, B, Carnegie, G, Carter, A, Heller, C, Watty, K, Hancock, P \& De Lange, P 2015, Shaping the future of accounting in business education in Australia, CPA Australia, Melbourne.

Parks, ES 2015, 'Listening with Empathy in Organizational Communication

', Organization Development Journal; Chesterland, vol. 33, no. 3, pp. 9-22.

Pia Patricia, PT 2017, 'Accounting Students' Perspective of Work-Relevant Communication Skills: Evidence From a Philippine University', i-Manager's Journal on English Language Teaching, vol. 7, no. 1, Jan/Mar 2017, pp. 30-32. https://doi.org/10.26634/jelt.7.1.11405

Queensland University of Technology 2019, 'Accountancy in practice', viewed 9 May 2019, $<$ https://www.qut.edu.au/business/about/schools/school-of-accountancy $>$.

Reddrop, A 2012, 'Family business engagement', School of Management, University of South Australia, Adelaide. 
Siriwardane, HP, Low, KY \& Blietz, D 2015, 'Making entry-level accountants better communicators: A Singapore-based study of communication tasks, skills, and attributes', Journal of Accounting Education, vol. 33, no. 4, 2015/12/01/, pp. 332-47. https://doi.org/10.1016/j.jaccedu.2015.08.001

Southern Cross University 2019, 'Bachelor of Accounting course', viewed 6 May 2019, $<$ https://www.scu.edu.au/study-at-scu/units/com00207/2019>.

Stone, G \& Lightbody, M 2012, 'The nature and significance of listening skills in accounting practice', Accounting Education, vol. 21, no. 4, pp. 363-84. https://doi.org/10.1080/09639284.2011.617062

Stone, G, Lightbody, M \& Whait, R 2013, 'Developing accounting students' listening skills: barriers, opportunities and an integrated stakeholder approach', Accounting Education: an international journal vol. 22, no. 2, pp. 168-92. https://doi.org/10.1080/09639284.2013.766015

Susskind, DS, Richard 2017, The Future of the Professions: how technology will transform the work of human experts, OUP, Oxford. https://doi.org/10.1016/S2155-8256(17)30099-6

Sydney University 2019, 'Master of Professional Accounting course', $<$ http://sydney.edu.au/handbooks/business_school_PG/coursework/professional_account ing/professional_accounting.shtml $>$.

Tempone, I, Kavanagh, M, Segal, N, Hancock, P, Howieson, B \& Kent, J 2012, 'Desirable generic attributes for accounting graduates into the twenty-first century: The views of employers', Accounting Research Journal, vol. 25, no. 1, pp. 41-55. https://doi.org/10.1108/10309611211244519

Twomey, D 2004, 'Adding empathy to the bottom line', Accountancy Ireland, vol. 36, no. 1, pp. 28-9.

Victoria University 2019a, 'Graduate Diploma in Business (Accounting) course', $<$ https://www.vu.edu.au/courses/graduate-diploma-in-business-accounting-bgar>.

Victoria University 2019b, 'Master of Business Accounting course', viewed 8 May 2019, $<$ https://www.vu.edu.au/courses/master-of-business-accounting-bmak $>$.

Western Sydney University 2019, 'Master of Professional Accounting (Advanced)', vol. , viewed 8 May 2019, $<$ http://handbook.westernsydney.edu.au/hbook/course.aspx?course=2746.2 $>$. 